\title{
Investigations of the emission characteristics of a gas turbine combustor with water steam injection
}

\author{
K.S. Burunsuz, V. V. Kuklinovsky, S. I. Serbin
}

Admiral Makarov National University of Shipbuilding, 9 Heroes of Ukraine Avenue, Mikolaiv, 54002, Ukraine

The article is devoted to investigation of the possibilities of creating highly efficient and competitive Ukrainian gas turbine engines (GTEs), which correspond to modern environmental requirements for new generation energy modules. One of the most important directions of solving this problem is considered, namely, the possibility of realizing a complex thermal circuit of a gas turbine unit (GTU) - the scheme "Aquarius" with the utilization of exhaust gases heat and the injection of ecological and energy water steam into the flowing part of a combustor. The possibilities of reducing emission of harmful components, in particular, of nitrogen oxides, are analyzed, while organizing the process of a $25 \mathrm{MW}$ gas turbine combustor with the supply of water steam to the primary and secondary chamber's zones. Three-dimensional calculations of the aerodynamic structure of chemically reacting flows in a gas turbine combustor were performed with the help of methods of computational fluid dynamics (CFD). The results of theoretical investigations of gas turbine combustor's emission characteristics at different ratios of the ecological and energy steam consumptions are presented, their rational values are revealed. The main results of the work can be used at power engineering enterprises for upgrading and modernizing existing and designing models of low-emission combustors of GTE.

Keywords: Combustor, Gas turbine engine, Toxic component, Nitrogen oxide.

\section{doi: https://doi.org/10.15673/ret.v55i2.1356}

(C) The Author(s) 2019. This article is an open access publication

This work is licensed under the Creative Commons Attribution 4.0 International License (CC BY) http://creativecommons.org/licenses/by/4.0/

\section{Introduction}

An important direction of raising the efficiency of using hydrocarbon fuel and reduction of its consumption, increasing the operation and environmental parameters of up-to-date stationary and transport power systems is usage of modern methods of upgrading operation in the combustors. Task-oriented usage of environmental friendly technologies is urgent which allow mitigation of the main pollutants emission.

Applying of gas turbine units is one of the prospective directions of upgrading power systems, increasing their economical efficiency, environmental compatibility and reliability. Due to this, the latest decade shows special intense development of gas turbine engineering in the technically developed countries, including Ukraine.

The main requirements for modern GTUs apart from economical efficiency, reliability and long service life are also a significantly low level of pollutants emission and high stability of combustors.

Nitrogen oxides $\left(\mathrm{NO}_{\mathrm{x}}\right)$ have the highest toxicity and their part can reach $90-95 \%$ in the total toxicity of exhaust gases of GTUs in the nominal mode. Depending on the formation mechanism nitrogen oxides can be divided into the following types [1,2]: thermal (at atmosphere nitrogen oxidation in afterflame processes), overbalance (due to fast reactions in the flame front) and fuel (at oxidation of nitrogen in the fuel). Their absolute amounts and correlations can differ depending on the factors which influence the oxidation processes and on fuel nitrogen content.

One of the most perspective methods for decreasing the thermal nitrogen oxides emission is the water steam injection into the primary flame zone, which reduces the flame temperature. In the other way, decreasing of the temperature inevitably causes the destabilization of the burning processes, especially for the partial modes of the gas turbine work.

The development of a new generation of gas turbine combustors should be based on better understanding of the physical and chemical processes of turbulent combustion in highly recalculating flows and ability of such combustors modeling taking in account complicity of their 3D geometry and variety of operation modes [3, 4]. Due to intensive development and achieved progress in numerical solutions of 
the fluid dynamics and chemical kinetics equations it is now possible to model the main physical and chemical processes inside combustors that are difficult to study experimentally. That could dramatically reduce expenses required for research and development of perspective combustors.

The goal of the presented article is to investigate the emission characteristics of the combustor of a 25 MW gas turbine unit with the utilization of exhaust gases heat and the injection of ecological and energy water steam into the flowing chamber's part.

\section{Research object}

An efficient method of hazardous emission suppression in GTE combustors is supply of a small amount of water or steam to the combustion zone. There are so called combustors with a "wet" way of toxic components emission suppression (wet low emission WLE). Combustion zone cooling and significant (by 30-40\%) reduction of nitrogen oxides emission take place [5-7]. This method is especially urgent in the diagrams of gas turbine units with a heat recovering loop when a part of steam (so called ecological steam) is supplied to the primary zone of the combustor for suppression of nitrogen compounds formation.

Figure 1 shows a diagram of a combustor by General Electric GE Frame 6B with injection of preliminary prepared fuel and steam mixture via fuel nozzles and power-generating steam via specific steam nozzles. These nozzles are installed in the intertube space [5]. It should be mentioned that there is additional supply of cooling steam to jet vanes of the first turbine stage. In order to control the parameters of the contact unit the steam temperature and pressure are controlled in all the piping of its supply. Such diagram provides stable parameters of combustion, a low noise and vibration level and significantly decreases hazardous components emission.

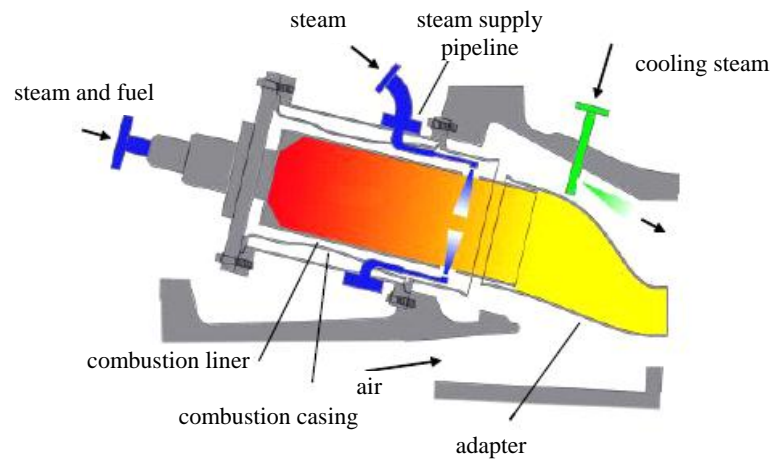

Figure 1 -Diagram of a combustor GE Frame with steam injection

The gas-pumping aggregate GPU-16K installed at the Stavischens'ka compressor station (Cherkasy region, Ukraine) is equipped with $16 \mathrm{MW}$ gas turbine unit with water steam injection. A combustor of the GTU of the "Aquarius" type produced by Gas Turbine Research and Production Complex "Zorya""Mashproekt" (Mykolayiv) is a diffusion combustor of a pipe-annular type (Fig. 2) with 10 combustion liners [6-7]. The main special feature of this design is supply of ecological water steam to the primary combustion zone and power-generating steam to the mixing zone which allows increasing the specific engine power and significant improving of ecological parameters.

For the investigation of the ecological characteristics the thermal scheme of the "Aquarius" type gas turbine unit (Fig. 2) was selected which allows to separate moisture from the exhaust gases for its reuse in the thermodynamic cycle.

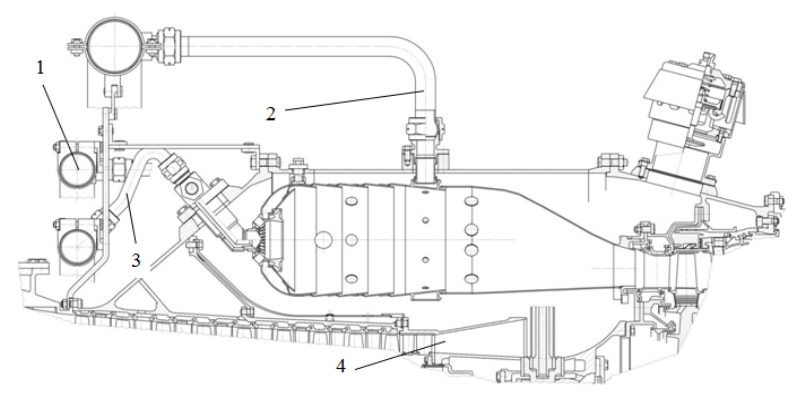

Figure 2-GTU combustor with water steam injection:

1 - ecological steam supply; 2 - power-generating steam supply; 3 - gas supply; 4 - air input after a high-pressure compressor

Note that earlier at the National University of Shipbuilding theoretical investigations of the working process in a gas turbine combustor with water steam injection were carried out [7], and they were also verified according to model and full-scale physical experiments.

The modeling of physical and chemical processes in a gas turbine combustor with steam injection was based on the averaging of systems of equations using partial derivatives which describe the mass, energy, momentum and chemical component conservation laws in the multicomponent reacting turbulent system $[3,7]$.

Diagrams of the exit $\mathrm{NO}_{\mathrm{x}}$ concentrations as a function of the relative power $N_{e}$ (Fig. 3) were constructed [7] to show the results of the numerical and full-scale experimental tests. The essential difference between the calculations and the experimental data can be seen only for the operating modes with energy steam injection. The use of proposed chemical mechanisms [7] gave good agreement with experimental data for the operating 
modes with ecological and energy steam injection. That is very important because these modes are basic ones for gas-and-steam turbine power plants.

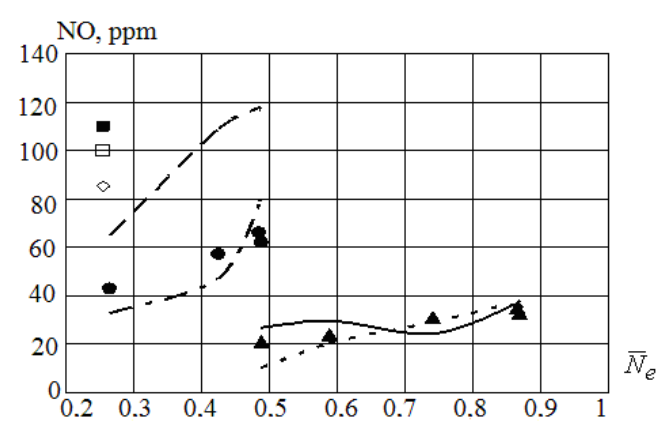

Figure 3 - Calculated and measured NO emission:

- - without steam injection (experiment); - - energy steam injection (experiment); $\mathbf{\Delta}-$ ecological and energy steam injection (experiment); $\mathbf{\square}, \diamond, \ldots \_-\ldots . ., \ldots$ calculation with different mechanism for $\mathrm{CO}$ formation

Calculations [7] were carried out for the gas turbine unit GTU-16K with relatively low parameters of the working fluid (the maximum gas temperature at the turbine inlet is $1374 \mathrm{~K}$ and the total air pressure after the compressor is $1.88 \mathrm{MPa}$ ). Therefore, when designing novel gas turbine engines with increased inlet turbine gas temperatures and pressure ratios, it is necessary to determine the influence of the ratio of ecological and energy steam flow rates on the main combustor's ecological characteristics, namely the nitrogen and carbon oxides in the exhaust.

\section{Research results}

Using the methods of computational fluid dynamics (CFD) three-dimensional calculations of the working process inside the combustor of a promising gas turbine unit with power of $25 \mathrm{MW}$ and water steam injection were carried out. The initial parameters of the working medium: the maximum gas temperature at the turbine inlet is $1600 \mathrm{~K}$ and the total air pressure after the compressor is $2.50 \mathrm{MPa}$.

For numerical calculations a geometric model of the 1/16 part of the internal space of a gas turbine combustor with injection of water steam into the flame tube flowing part was created (Fig. 4).

The combustor has an annular design with ten flame tubes. The main feature of its design is feeding ecologically-beneficial water steam into the primary combustion zone and energy-beneficial steam into the mixing zone, which allows an increase in specific engine power and considerably enhances the ecological characteristics.

On the basis of the geometric model a finiteelement model of the 1/16 part of a gas turbine combustor was created (Fig. 5).

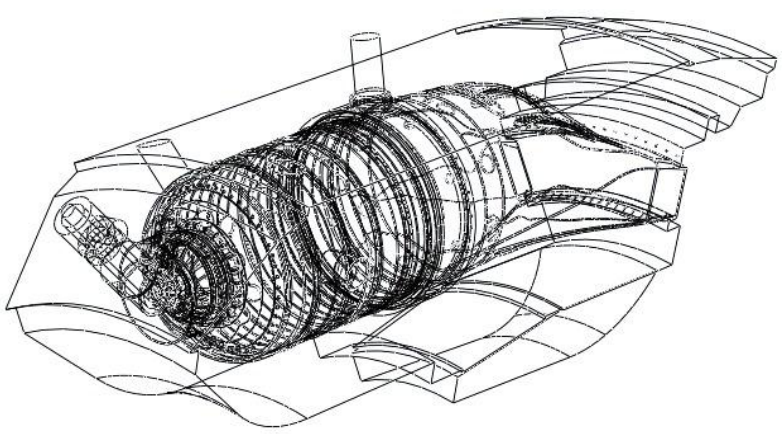

Figure 4-Three-dimensional geometric model of a combustor

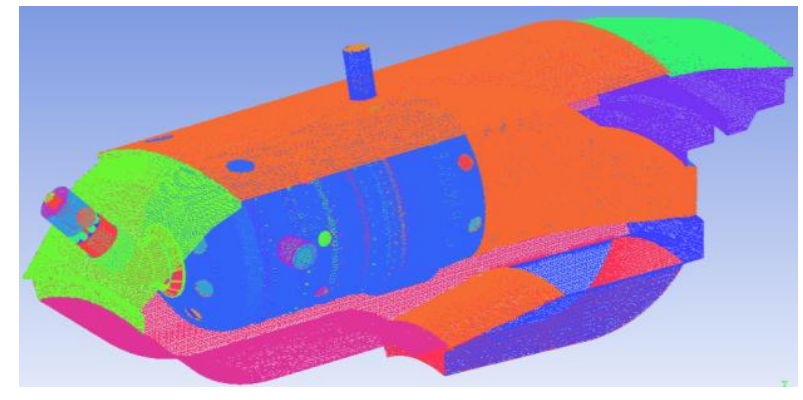

Figure 5 - Finite-element gas turbine combustor's model

For gas turbine combustor with steam injection calculation the Eddy-Dissipation-Concept (EDC) model (detailed Arrhenius chemical kinetics incorporated in flames with turbulent fluctuations) has been used.

The EDC model assumes that reaction occurs in small turbulent structures, called fine scales. Species react in the fine structures over a timescale. Reactions proceed over the timescale, governed by Arrhenius rates and are integrated numerically using special algorithm $[8,9]$.

The mathematical model of the nitrogen oxides emission used in this article is a system of mass transfer equations that takes into consideration convection, diffusion, as well as the formation and decomposition of $\mathrm{NO}$ and related compounds, and is derived on the basis of the law of conservation of mass. The influence of the reagent residence time in a reactive volume on the mechanism of $\mathrm{NO}_{\mathrm{x}}$ formation is taken into consideration in the convective terms of the defining equations recorded in the Euler reference frame. For "thermal" and "fast" nitrogen oxides the transport equation for $\mathrm{NO}$ is to be solved, written in a vector form, based on the equation of mass conservation for individual chemical components of the mixture [9]:

$$
\frac{\partial}{\partial t}\left(\rho Y_{\mathrm{NO}}\right)+\nabla \cdot\left(\rho \vec{v} Y_{\mathrm{NO}}\right)=\nabla \cdot\left(\rho D \nabla Y_{\mathrm{NO}}\right)+S_{\mathrm{NO}}
$$

where $\rho$ is the density; $Y_{\mathrm{NO}}$ is the mass concentration of NO; $D$ is the diffusion coefficient; $\vec{v}$ is the velocity 
vector; $Y_{\mathrm{NO}}$ is the source term, which is determined by the mechanism of $\mathrm{NO}_{\mathrm{x}}$ formation.

For the prediction of the $\mathrm{CO}$ emission, a global two-step mechanism of methane oxidation was used as well as its modification with an additional third reaction for $\mathrm{CO}_{2}$ decomposition. The Arrhenius equation was used to calculate reaction rate constants for all the reactions. Necessary values for the reaction rates calculation are shown in Table 1. Presented kinetic mechanisms are included in the mathematical model of the 3-D reacting flow for carrying out numerical experiments with implementation of the CFD complex.

Table 1 - Mechanisms of methane oxidation

\begin{tabular}{|c|c|c|c|c|c|c|c|c|}
\hline 跑 & Reaction & $A$ & $\begin{array}{l}\text { 음 } \\
\text { हn }\end{array}$ & $\beta$ & \multicolumn{4}{|c|}{ Reaction order } \\
\hline \multirow{2}{*}{1} & $\mathrm{CH}_{4}+1,5 \mathrm{O}_{2} \rightarrow \mathrm{CO}+2 \mathrm{H}_{2} \mathrm{O}$ & $5.12 \mathrm{e}+11$ & $2 \mathrm{e}+08$ & 0 & $\mathrm{CH}_{4}$ & 0.7 & $\mathrm{O}_{2}$ & 0.8 \\
\hline & $\mathrm{CO}+0,5 \mathrm{O}_{2} \rightarrow \mathrm{CO}_{2}$ & $2.39 \mathrm{e}+12$ & $1.7 \mathrm{e}+08$ & 0 & $\mathrm{O}_{2}$ & 0.25 & $\mathrm{CO}$ & 1 \\
\hline \multirow{3}{*}{2} & $\mathrm{CH}_{4}+1,5 \mathrm{O}_{2} \rightarrow \mathrm{CO}+2 \mathrm{H}_{2} \mathrm{O}$ & $4.4 \mathrm{e}+9$ & $1.17 \mathrm{e}+8$ & 0.062 & $\mathrm{CH}_{4}$ & 0.5 & $\mathrm{O}_{2}$ & 1.066 \\
\hline & $\mathrm{CO}+0,5 \mathrm{O}_{2} \rightarrow \mathrm{CO}_{2}$ & $3.7 \mathrm{e}+11$ & $7.68 \mathrm{e}+7$ & 0.215 & $\mathrm{O}_{2}$ & 1.756 & $\mathrm{CO}$ & 1.258 \\
\hline & $\mathrm{CO}_{2} \rightarrow \mathrm{CO}+0,5 \mathrm{O}_{2}$ & $6.02 \mathrm{e}+5$ & $1.31 \mathrm{e}+8$ & $0 j 08$ & $\mathrm{CO}_{2}$ & 1.357 & & \\
\hline
\end{tabular}

The proposed mathematical model is used for investigation of the working processes in a gas turbine combustor with injection of ecological and energy steam. Design features of a considered combustor indicate dominance of a diffusive mechanism of burning. A numerical experiment with different ratios of ecological and energy steam was conducted.

Figure 6 shows the temperature field in the longitudinal section of the combustor of $25 \mathrm{MW}$ "Aquarius" type GTU with different ratios of ecological and energy steam. With an increase in the amount of ecological steam a decrease in the temperature of the working fluid in the primary combustion zone is observed.

The concentrations of nitrogen oxide in the longitudinal section of the "Aquarius" type gas turbine tube are significantly reduced with the increase in the flow rate of ecological steam (Fig. 7), and the concentration of carbon monoxides is slightly changed (Fig. 8).

As a result of numerical three-dimensional experiments with different ratios of the ecological and energy steam, a graphs of the dependence of $\mathrm{NO}$ and $\mathrm{CO}$ emissions in the outlet section of a gas turbine combustor on the ratio of the flow rates of the ecological and energy steam were obtained (Fig. 9).

There is a decrease in emissions of nitrogen oxides NO with an increase in the flow rate of ecological steam. So, when the ratio of the mass flow rate of the ecological steam to the energy steam is $0.45 / 0.55$, the lowest calculated emission of nitrogen oxides is $37.9 \mathrm{ppm}$.
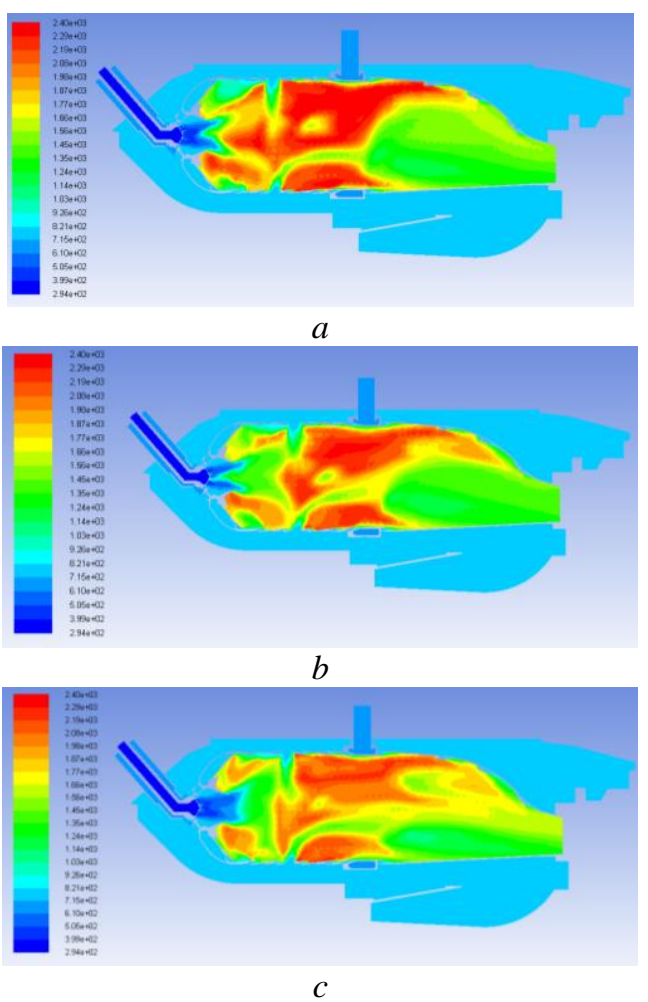

Figure 6 - Temperature field in the longitudinal section of the fire tube with different ratio of the ecological and energy steam:

a) $0.15 / 0.85$; b) $0.25 / 0.75$; c) $0.40 / 0.60$
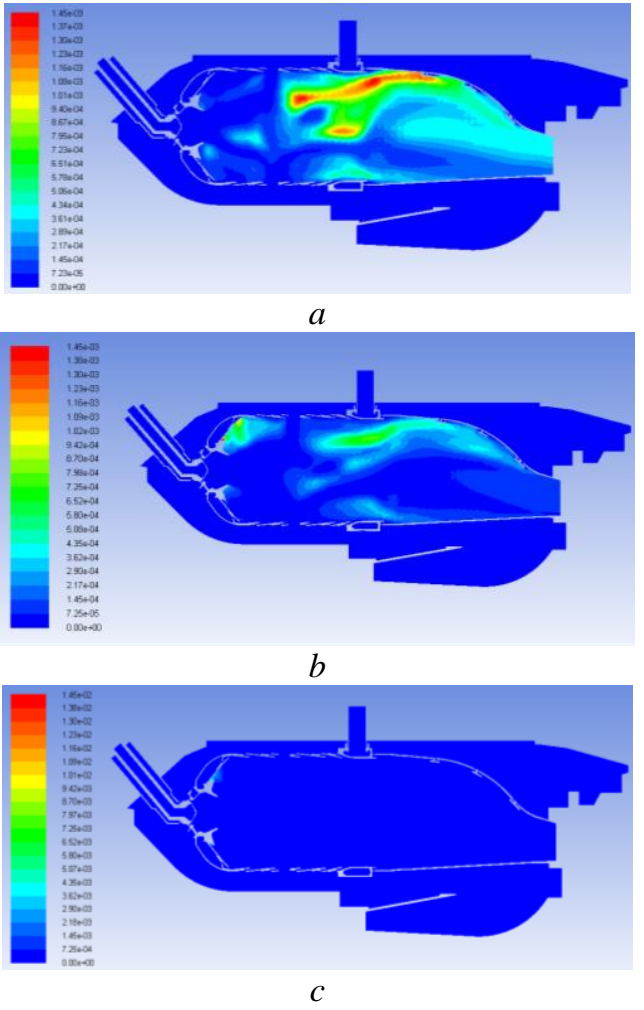

Figure 7 - Nitrogen oxide concentration in the longitudinal section of the fire tube with different ratio of the ecological and energy steam: a) $0.15 / 0.85 ; b$ ) $0.25 / 0.75$; c) $0.40 / 0.60$ 

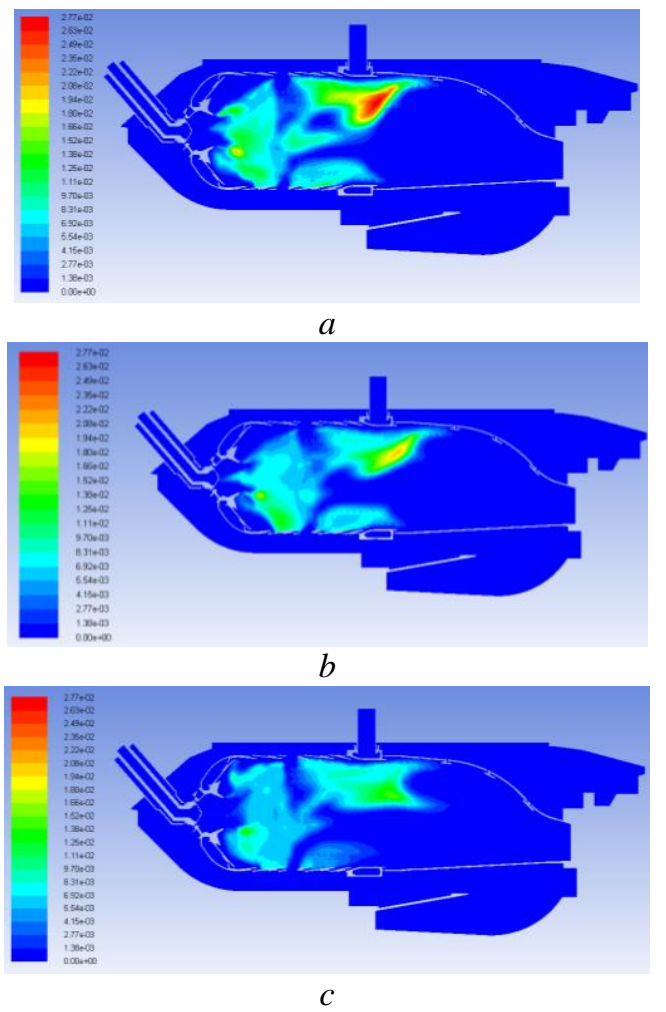

Figure 8 -Carbon monoxide concentration in the longitudinal section of the fire tube with different ratio of the ecological and energy steam:

a) $0.15 / 0.85$; b) $0.25 / 0.75$; c) $0.40 / 0.60$

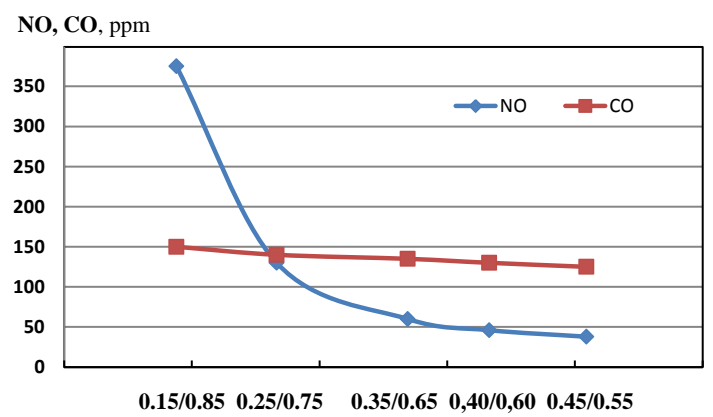

Figure 9-Dependences of $\mathrm{NO}$ and $\mathrm{CO}$ emissions on the ratio of ecological and energy flow rates

Taking into consideration the mixing of the cooling air with the combustion products in the turbine flow part (about 12\%), the estimated emission of nitrogen oxides in the GTU exhaust system will be about $30 \mathrm{ppm}$, which satisfy the modern European requirements for gas turbine engines working on gaseous fuels.

The temperature field in the outlet section of the combustor's flame tube is shown in Fig. 10.

The nonuniformity of the temperature field is significantly affected by the inequality of water steam supply into the fire tube, which arises due to the unequal flow of water steam through the holes in the primary and secondary combustor's zones when passing

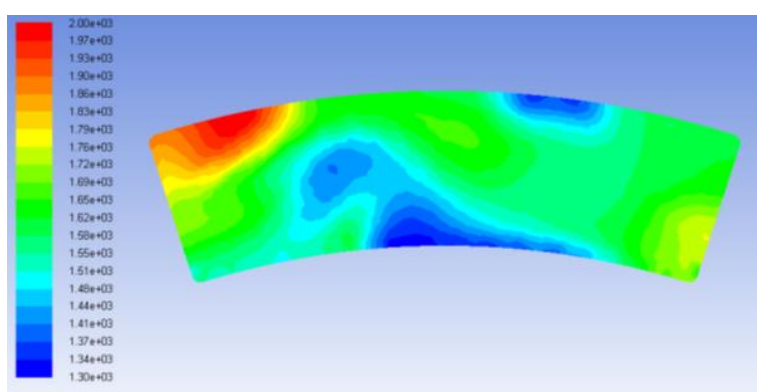

Figure 10 - Temperature field in the outlet section of the flame tube

through the steam collectors. This issue must be given considerable attention when modifying combustor design during experimental tests.

\section{Conclusions}

1. The analysis of the main directions of toxic components emission reduction in combustors of gas turbine engines working on hydrocarbon fuels has been carried out, as well as a promising means of minimizing nitrogen oxides emissions due to implementation of the thermal scheme "Aquarius" with waste heat utilization and injection of ecological and energy water steam into the combustor's flowing part.

2. A three-dimensional mathematical model of turbulent chemically reacting flows in combustors of the gas turbine engines, which is based on the numerical solution of the system of differential equations describing the basic laws of conservation of energy and the transport of chemical components in a turbulent chemically reacting system, has been further developed.

3. For the first time theoretical investigations of influence of the distribution of ecological and energy water steam flow rates on the ecological characteristics of $25 \mathrm{MW}$ gas turbine unit operating on gaseous fuel have been carried out.

4. It was found that the nonuniformity of the temperature field at the combustor's outlet is significantly influenced by the unevenness of water steam supply into the fire tube, which arises due to the unequal flow of water steam through the holes in the primary and secondary combustor's zones

5. Taking into consideration the mixing of the cooling air with the combustion products in the turbine's flow part, the estimated emissions of nitrogen oxides in the gas turbine exhaust system will be about $30 \mathrm{ppm}$, which satisfy the modern European requirements.

\section{References}

1. Hristich V. A., Tumanovsky A. G. Gas turbine engines and environmental protection. - Kyiv: Technique, 1983 - 144 p. (in Russian). 
2. Mellor A. M. Atmospheric pollution by gas turbine engines // Formation and decomposition of pollutants in a flame. - Moscow: Machine-building. - 1981. - P. 217-260 (in Russian).

3. Launder B. E., Spalding D.B. Mathematical Models of Turbulence. - London: Academic Press, 1972. $-310 \mathrm{p}$.

4. Matveev, I., Serbin, S., Mostipanenko, A. Numerical Optimization of the "Tornado" Combustor Aerodynamic Parameters // 45th AIAA Aerospace Sciences Meeting and Exhibit, Reno, Nevada, AIAA 2007391. - 2007. - P. 1-12.

5. Nelson A. Quick and economical power augmentation and emission control using new advancements in combustion turbine steam injection // Session 12.C. Combustion turbine performance augmentation. Cheng Power Systems, 2001. - 21 p.

6. Operating experience of the gas turbine unit GPU16K with steam injection / Y. N. Bondin, V. A. Krivutsa, S. N. Movchan, V. I. Romanov, V. N.
Kolomeev, A. P. Shevchov // Gas turbine technologies. - 2004. - № 5. - P. 18-20 (in Russian).

7. Serbin S., Mostipanenko A., Matveev I. Investigation of the Working Processes in a Gas Turbine Combustor with Steam Injection // Proceedings of the ASME/JSME 8th Thermal Engineering Joint Conference AJTEC2011, USA, AJTEC2011-44042. - 2011. $-6 \mathrm{p}$.

8. Serbin S., Goncharova N. Investigations of a Gas Turbine Low-Emission Combustor Operating on the Synthesis Gas // International Journal of Chemical Engineering. - 2017. - Vol. 2017. - 14 p.

9. Serbin S.I., Kozlovskyi A.V., Burunsuz K.S. Investigations of Nonstationary Processes in Low Emissive Gas Turbine Combustor with Plasma Assistance // IEEE Transactions on Plasma Science. - 2016. Vol. 44, Issue 12. - P. 2960-2964.

Received 05 February 2019 Approved 02 April 2019 Available in Internet 30 April 2019

\title{
Дослідження емісійних характеристик газотурбінної камери згоряння з впорскуванням водяної пари
}

\section{К. С. Бурунсуз, В. В. Кукліновський, С І. Сербін}

Національний університет кораблебудування ім. адм. Макарова, просп. Героїв України, 9, Миколаїв, 54002, Україна

\begin{abstract}
Стаття присвячена дослідженню можливостей створення високоефективних і конкурентоспроможних вітчизняних газотурбінних двигунів (ГТД), що відповідають сучасним екологічним вимогам до енергетичних модулів нового покоління. Розглянуто один з актуальних напрямків вирімення иієї проблем, а саме можливості реалізаиії складної теплової схеми газотурбінної установки (ГТУ) схеми "Водолій" з утилізацією теплоти відпрацьованих газів та впорскуванням екологічної та енергетичної водяної пари в проточну частину камери згоряння. Проаналізовано можсливості зменшення викидів шкідливих компонентів, зокрема повітряних оксидів азоту, при організації робочого прочесу камери згоряння газотурбінної установки потужністю 25 МВт з подачею водяної пари в первинну та вторинну частину камери. За допомогою методів обчислювальної гідродинаміки (CFD) проведено тривимірні розрахунки аеродинамічної структури хімічно реагуючих потоків в газотурбінній камері згоряння. Представлено результати теоретичних досліджень емісійних характеристик газотурбінної камери згоряння при різних співвідношеннях витрат екологічної та енергетичної пари, виявлено їх раціональні значення. Основні результати роботи можуть бути використані на підприємствах енергомашинобудування при доводиі й модернізації існуючих і проектуванні перспективних зразків низькоемісійних камер згоряння ГТД.
\end{abstract}

Ключові слова: Камера згоряння, Газотурбінна установка, Токсичний компонент, Оксид азоту.

\section{Література}

1. Христич В. А. Газотурбинные двигатели и защита окружающей среды. - К.: Техніка, 1983. $144 \mathrm{c}$.

2. Меллор А. М. Загрязнение атмосферы газотурбинными двигателями // Образование и разложение загрязняющих веществ в пламени : пер. с англ. - М.: Машиностроение, 1981. - С. 217-260.
3. Launder B. E., Spalding D.B. Mathematical Models of Turbulence. - London: Academic Press, 1972. $-310 \mathrm{p}$.

4. Matveev, I., Serbin, S., Mostipanenko, A. Numerical Optimization of the "Tornado" Combustor Aerodynamic Parameters // 45th AIAA Aerospace Sciences Meeting and Exhibit, Reno, Nevada, AIAA 2007391. - 2007. - P. 1-12. 
5. Nelson A. Quick and economical power augmentation and emission control using new advancements in combustion turbine steam injection // Session 12.C. Combustion turbine performance augmentation. Cheng Power Systems, 2001. - 21 p.

6. Опыт эксплуатации газотурбинной установки ГПУ-16К с впрыском пара / Ю. Н. Бондин, В. А. Кривуца, С. Н. Мовчан, В. И. Романов, В. Н. Коломеев, А. П. Шевцов // Газотурбинные технологии. - 2004. - № 5. - С. 18-20.

7. Serbin S., Mostipanenko A., Matveev I. Investigation of the Working Processes in a Gas Turbine Combustor with Steam Injection // Proceedings of the ASME/JSME 8th Thermal Engineering Joint Confer- ence AJTEC2011, USA, AJTEC2011-44042. - 2011. $-6 \mathrm{p}$.

8. Serbin S., Goncharova N. Investigations of a Gas Turbine Low-Emission Combustor Operating on the Synthesis Gas // International Journal of Chemical Engineering. - 2017. - Vol. 2017. - 14 p.

9. Serbin S.I., Kozlovskyi A.V., Burunsuz K.S. Investigations of Nonstationary Processes in Low Emissive Gas Turbine Combustor with Plasma Assistance // IEEE Transactions on Plasma Science. - 2016. Vol. 44, Issue 12. - P. 2960-2964.

\footnotetext{
Отримана в редакції 05.02.2019, прийнята до друку 02.04.2019
} 